\title{
Sexual Behaviour among Higher Secondary School Students of Kathmandu Metropolitan City
}

\author{
Khanal $\mathbf{P}^{1}$ \\ ${ }^{1}$ District AIDS Coordination Committee, District Health Office, Gulmi, Nepal
}

\begin{abstract}
Background:Lack of knowledge and skills to avoid risky behaviour and lack of access to youth- friendly reproductive health information and services place young people in a position of great vulnerability.Adolescents are at the stage of experimentation and are easily influenced by their peers and are therefore a vulnerable population at risk for HIV/ AIDS and other STIs. Safe sexual behaviour has a crucial role in the prevention of problems related to sexual and reproductive health. The study was designed to explore the sexual behaviour among students of Higher Secondary School in Kathmandu Metropolitan City.
\end{abstract}

Methods: The study was cross-sectional and a total of 268 students enrolled in 12th grade from 6 Higher Secondary Schools were involved in the data collection process. Data collection was done using anonymous, self-administered questionnaire

Results: Among total 263 unmarried students, nearly onefifth $(17.9 \%)$ students have ever had sexual contact. Study showed that nearly half of the sexually experienced students $(46.8 \%)$ were involved in unsafe sexual behaviour.

Conclusion: Nearly one-fifth students had premarital sex and nearly half of the students had been involved in unsafe sexual behavior. Based on the findings, the study recommends that the major concern should be on making the sexual relations safe and it is therefore necessary to encourage young people to be consistent condom users.

Key words: Sexual behaviour, Students, Condom

\section{Introduction}

Adolescence is a period of transition from childhood to adulthood. It is a period between 10-19 years of age in which physical, psychological and social maturing take place. During these years, following puberty, young people gradually mature to become adults, but do not generally assume the privileges, roles and responsibilities commonly associated with adulthood. Nonetheless, this is the age when most people begin to explore their sexuality and have sexual relationships. Sexual activity during adolescence (within or outside marriage) puts adolescence at risk of sexual and reproductive health problems. These include early pregnancy, unsafe abortion, sexually transmitted infections (STIs) including HIV, and sexual coercion and violence. In many parts of the world, sexual and reproductive health needs of adolescents are either poorly understood or not fully appreciated.

Lack of knowledge and skills to avoid risky behaviour and lack of access to youth- friendly reproductive health information and services place young people in a position of great vulnerability.Adolescents are at the stage of experimentation and are easily influenced by their peers and are therefore a vulnerable population at risk for HIV/AIDS and other STIs. As of 2009 AD, national estimates indicate that approximately 63,528 adults and children are infected with HIV virus in Nepal with prevalence of about 0.39 in the adult population. Out of the total 63,528 persons with HIV infection, 41, 509 are males while 22,019 are females. Adolescents (10-19 years) and Young people of age group (20-24) account for $15 \%$ of the total HIV infections in Nepal. About $90 \%$ of HIV infections are occurred through sexual transmission. (1)

The objectives of the study were to identify the prevalence of premarital sexual intercourse, age at first sexual contact, identify the major source of information used by students for messages on reproductive health, explore number of and relationship with sexual partner among sexually active students, find out the pattern of sex practices among the sexually active participants and to analyze the factors associated with sexual behaviour.

\section{Methods}

A descriptive, cross-sectional study was conducted among Higher Secondary Students. The study was cross-sectional and a total of 268 students enrolled in 12th grade from 6 Higher Secondary Schools were involved in the data collection process. Data collection was done in the month of July, 2011 using anonymous, self-administered questionnaire. Stratified random sampling technique was applied to select higher secondary schools. One higher secondary school was selected from each of the geographically divided sectors of Kathmandu Metropolitan City.In a higher secondary school, students of a stream of a classroom were also selected randomly.

Pretesting of tools was done in a similar setting in a Higher Secondary School in Gongabu VDC. Verbal consent was taken from the college administration as well as from the students and then the information was gathered by using selfadministered questionnaire. Students were assured for maintenance of their confidentiality; sitting arrangement was

CORRESPONDENCE : Pratik Khanal, District AIDS Coordinator, District AIDS Coordination Committee, District Health Office, Gulmi, Nepal. Email: khanal_pratik@yahoo.com 
modified to maintain privacy. Similarly, students were asked to submit their filled questionnaires by putting it in a safe box.

SPSS version 17 for windows was used in data entry and analysis. A total of 5 responses with non-consistent data were discarded. Odds ratio and confidence interval were collected at $95 \%$ significance level. Chi-square test was used to determine the factors associated with sexual behaviour.

Data analysis was carried out in two phases:-Univariate analysis: For all dependent and independent variables percentage was calculated for each category.Bivariate analysis: The association of different independent variable with dependent variable was determined by cross tabulation using chi-square test along with the computation of odds ratio.

Sexual behaviourrefers to the manner in which humans experience and express their sexuality. It has been categorized into safe and unsafe. It is the composite variable of consistency of condom use (for student who have had at least two sexual contacts) and condom use at last sexual contact (for student who has had only one sexual contact). Adherence to the above definition is regarded as safe; otherwise unsafe

\section{Results}

A total of 268 responses were collected. However, only 263 responses were analyzed as 5 responses were discarded due to lack of internal consistency.

Majorities of the respondents were in the age group 16-17 years $(59.3 \%)$. The average age of the respondents was 17.35 years. While more boys than girls $(51.7 \%$ vs. $48.3 \%)$ participated in the study, all of the respondents were unmarried. Only $9.5 \%$ of the respondents had broken family and Majority of the respondents $(71.1 \%)$ stayed with their parents currently.

Table 1: Demographic characteristics

\begin{tabular}{l|c|c}
\hline \multicolumn{1}{c|}{ General Characteristics } & Number $(\mathbf{= 2 6 3 )}$ & Percentage \\
\hline Age & 156 & 59.3 \\
$16-17$ & 107 & 40.7 \\
18 and above & & \\
\hline Sex & 136 & 51.7 \\
Male & 127 & 48.3 \\
Female & & \\
\hline Marital Status & 263 & 100 \\
Unmarried & - & - \\
Married & & \\
\hline Family Structure & 238 & 90.5 \\
Intact & 25 & 9.5 \\
Broken & 187 & \\
\hline Current Residence & 48 & 71.1 \\
With parents & 28 & 18.3 \\
With Relatives & & 10.6 \\
Alone or with friends & & \\
\hline
\end{tabular}

The major source of information on sexual and reproductive health as citied by the respondents were Media/Newspaper (58.9\%), Teachers (55.5\%), Friends (39.2\%), Family (26.2\%), and Health Workers (25.1\%).

More than half $(60.1 \%)$ of the students watched sexually excite materials. 88 percentage of boys and $29.9 \%$ of girls watched sexually excite materials. The major source used to watch sexually excite materials is Films/ DVD (82.3\%) followed by Internet (46.8\%).

Only $29.3 \%$ respondents ( $48.5 \%$ boys and $8.6 \%$ girls) had liberal attitude towards sex while $38 \%$ of the respondents ( $64 \%$ boys and $10.2 \%$ girls) had sexually experienced peer. It was seen that $40.7 \%$ of respondents $(50.7 \%$ boys and $29.9 \%$ girls) had boy/ girl friend (table 1).

Table 2: Source of information

\begin{tabular}{|c|c|c|}
\hline Study variables & Number $(n=263)$ & Percentage \\
\hline $\begin{array}{l}\text { Major Source of Information } \\
\text { on Sexual and reproductive } \\
\text { health (Multiple response) }\end{array}$ & & \\
\hline $\begin{array}{l}\text { Family } \\
\text { Friends } \\
\text { Teachers/ School education } \\
\text { Media/Newspaper } \\
\text { Health Workers }\end{array}$ & $\begin{array}{r}69 \\
103 \\
146 \\
155 \\
66\end{array}$ & $\begin{array}{l}26.2 \\
39.2 \\
55.5 \\
58.9 \\
25.1\end{array}$ \\
\hline $\begin{array}{l}\text { Watch Sexually excite } \\
\text { materials } \\
\text { Yes } \\
\text { No }\end{array}$ & $\begin{array}{l}158 \\
105\end{array}$ & $\begin{array}{l}60.1 \\
39.9\end{array}$ \\
\hline $\begin{array}{l}\text { Source of sexually excite } \\
\text { materials(Multiple response) } \\
\text { Internet } \\
\text { Films/DVD } \\
\text { Magazines }\end{array}$ & $\begin{array}{r}74 \\
130 \\
56\end{array}$ & $\begin{array}{l}46.8 \\
82.3 \\
35.4\end{array}$ \\
\hline $\begin{array}{l}\text { Premarital sex } \\
\text { Approve } \\
\text { Disapprove }\end{array}$ & $\begin{array}{r}77 \\
186\end{array}$ & $\begin{array}{l}29.3 \\
70.7\end{array}$ \\
\hline $\begin{array}{l}\text { Know peer having sex } \\
\text { Yes } \\
\text { No }\end{array}$ & $\begin{array}{l}100 \\
163\end{array}$ & $\begin{array}{l}38 \\
62\end{array}$ \\
\hline $\begin{array}{l}\text { Have boy/girl friend } \\
\text { Yes } \\
\text { No }\end{array}$ & $\begin{array}{l}107 \\
156\end{array}$ & $\begin{array}{l}40.7 \\
59.3\end{array}$ \\
\hline
\end{tabular}

Almost $18 \%$ of respondents have ever had sex. Premarital sex was $30.1 \%$ among boys and $4.7 \%$ among girls. Median age at first sexual contact was 16.0 years.Minimum and maximum age at first sexual intercourse was 14 and 21 years respectivelyMore than half of the sexually experienced students $(57.4 \%)$ had their first sexual intercourse with their boy/ girl friend while $25.5 \%$ have had with friends from school. Only $8.5 \%$ of the respondents had their sexual debut with sex workers and an equal proportion with strangers. About $68 \%$ of the sexually experienced students were sexually active (i.e. they have had sex within past 12 months preceding the re- 
search).

Objective of the first sexual encounter was found varied among the respondents. Nearly equal proportion of the students mentioned curiosity and pleasure seeking (31.9 and $34 \%$ ) as their objective behind first sexual intercourse. Notably 2 respondents $(4.3 \%)$ mentioned their first sexual intercourse as forced.Condom use during the first sexual intercourse was found to be $72.3 \%$. Condom use at last sexual contact for those who were experienced once was $62.5 \%$. While for those who had at least two sexual contacts, only $48.4 \%$ of the respondents used condom consistently during the sexual intercourse.

Frequency of the sexual exposure was once for nearly one out of three $(34 \%)$ of the respondents while $46.8 \%$ of the respondents had been sexually exposed more than two times.Slightly over a half $(51.1 \%)$ of the sexually experienced students had single sex partner while nearly a third (31.9\%) of the respondents had two sex partners and $17 \%$ of the sexually experienced respondents had more than two sex partners.

\begin{tabular}{|c|c|c|}
\hline Study variables & Number & Percentage \\
\hline $\begin{array}{l}\text { Ever had } \operatorname{sex}(\mathrm{N}=263) \\
\text { Yes } \\
\text { No }\end{array}$ & $\begin{array}{r}47 \\
216\end{array}$ & $\begin{array}{l}17.9 \\
82.1\end{array}$ \\
\hline $\begin{array}{l}\text { Age at first sexual contact }(\mathrm{N}=47) \\
14-16 \\
16 \text { and above }\end{array}$ & $\begin{array}{l}25 \\
22\end{array}$ & $\begin{array}{l}53.2 \\
46.8\end{array}$ \\
\hline $\begin{array}{l}\text { Partner in first encounter }(\mathrm{N}=47) \\
\text { Boy/Girl Friend } \\
\text { Friend from school } \\
\text { Stranger } \\
\text { Sex worker }\end{array}$ & $\begin{array}{r}27 \\
12 \\
4 \\
4\end{array}$ & $\begin{array}{c}57.4 \\
25.5 \\
8.5 \\
8.5\end{array}$ \\
\hline $\begin{array}{l}\text { Current sexual involvement } \\
\text { Active } \\
\text { Inactive }\end{array}$ & $\begin{array}{l}32 \\
15\end{array}$ & $\begin{array}{l}68.1 \\
31.9\end{array}$ \\
\hline $\begin{array}{l}\text { Objective behind first sexual } \\
\text { encounter } \\
\text { Curiosity } \\
\text { Pleasure } \\
\text { Forced } \\
\text { Accidental } \\
\text { Consensual }\end{array}$ & $\begin{array}{r}15 \\
16 \\
2 \\
4 \\
10\end{array}$ & $\begin{array}{c}31.9 \\
34 \\
4.3 \\
8.5 \\
21.3\end{array}$ \\
\hline $\begin{array}{l}\text { Frequency of Sexual exposure }(\mathrm{N}=47) \\
\text { Once } \\
\text { Twice } \\
\text { More than two times }\end{array}$ & $\begin{array}{r}16 \\
9 \\
22\end{array}$ & $\begin{array}{c}34 \\
19.2 \\
46.8\end{array}$ \\
\hline $\begin{array}{l}\text { Number of partner }(\mathrm{N}=47) \\
\text { Single } \\
\text { Two } \\
\text { More than two }\end{array}$ & $\begin{array}{r}24 \\
18 \\
8\end{array}$ & $\begin{array}{c}51 \\
31.9 \\
17\end{array}$ \\
\hline
\end{tabular}

Table 32: Sexual behaviors

Study showed that nearly half of the sexually experienced students $(46.8 \%)$ were involved in unsafe sexual behavior.

\begin{tabular}{l|c|c}
\hline \multicolumn{1}{c|}{ Sexual behavior } & Number( $n=47)$ & Percentage \\
\hline $\begin{array}{l}\text { Unsafe } \\
\text { Safe }\end{array}$ & 22 & 46.8 \\
\hline Used condom for the first time & & 53.2 \\
Yes & 34 & 72.3 \\
No & 13 & 27.7 \\
\hline $\begin{array}{l}\text { For those experienced once } \\
\text { condom use at the last sexual }\end{array}$ & & \\
contact & 10 & \\
Yes & 6 & 37.5 \\
No & & \\
\hline Consistency in condom use for & & \\
those with multiple & 15 & 48.4 \\
exposure(N=31) & 16 & 51.6 \\
$\begin{array}{l}\text { Yes } \\
\text { No }\end{array}$
\end{tabular}

Table 4: Practice of Safe sexual behaviors

\section{Discussion}

This research was attempted in order to explore the sexual behaviour and factors influencing it among higher secondary school students in Kathmandu Metropolitan City. Behaviour related to sex is one of the issues with special importance, especially considering the ever- increasing trend of STIs including HIV/ AIDS, combined with poor level of information in majority of these young people regarding their own sexuality. Furthermore, sexually experienced adolescents are typically unaware of the consequences of unprotected sexual intercourse and means of protecting themselves often leading to unwanted pregnancy and abortion which just not relate to health but also give rise to various social and economic repercussions. Although premarital sex is socially unacceptable in Nepal, past studies have shown that the proportion of sexually experienced before marriage has been on the rise.

Study showed that $17.9 \%$ of respondents have ever had sex. Premarital sex was $30.1 \%$ among boys and $4.7 \%$ among girls. Average age at first sexual contact was 16.45 years. Minimum and maximum age at first sexual intercourse was 14 and 21 years respectively. The similar study in Panauti Municipality of Kavre district, Nepal (2) showed $12.9 \%$ students of the secondary school have premarital sexual relations. Male were more likely $(18 \%)$ to have premarital sex than their female counterparts $(8.6 \%)$. Similarly, in a study in Baglung district of Nepal, average age at first sexual contact was 16.88 years .(3)

Findings from studies which have investigated premarital sexual behaviour among high school and college students have found rates of activity to vary from 11 percent among students in Pokhara to 14 percent among Kathmandu students and 16 percent among students in Palpa district. (4) These findings suggest that pre-marital sexual relationship is social facts and a substantial proportion of young people start 
sexual relations in middle adolescence, so adolescents' sexual and reproductive health policy and program should target young people right from early adolescence (10-14 years)

Since, students rely on media, teachers and friends as the important source of information on Sexual Reproductive Health; efforts should be made in conducting school based HIV prevention and education programs, teachers should be empowered to be effective health educators and counselors ;making media youth friendly and important resource to aware youths with correct information. Given that friends are an important source of information on health issues, it is important to pay more attention to developing quality and effective communication and trust skills among friends. Young people and their peers should have access to quality information

More than half $(60.1 \%)$ of the students watch sexually excite materials. The major source used to watch sexually excite materials is Films/ DVD (82.3\%) followed by Internet (46.8\%). Since advancements like internet, watching films/DVD has an effect on the adolescents and young peoples' behaviour; special caution should be taken by the students themselves and their parents and teachers about the risks vs. benefits of utilizing those technological developments.

Only $29.3 \%$ respondents had liberal attitude towards sex while $38 \%$ of the respondents had sexually experienced peer. Interestingly, $40.7 \%$ of respondents had boy/girl friend. The difference in sexual behaviour among the respondents who had boy/ girl friend and those who did not have boy/ girl friend was found statistically significant. More than half of the sexually experienced students $(57.4 \%)$ had their first sexual intercourse with their boy/ girl friend while $25.5 \%$ have had with friends from school. Only $8.5 \%$ of the respondents had their sexual debut with sex workers and an equal proportion with strangers. So, it is necessary that students should negotiate safe sexual behaviour with their sex partners.

Condom use during the first sexual intercourse was found to be $72.3 \%$. Condom use at last sexual contact for those who were experienced once was $62.5 \%$. While for those who had at least two sexual contacts, only $48.4 \%$ of the respondents used condom consistently during the sexual intercourse. These findings suggest that consistency in condom use decreases with the increase in frequency of sexual contact.There is still a lot to do in sensitizing young people to translate the theoretical knowledge into healthy sexual behaviour as young people fail to be consistent in condom use.

Objective of the first sexual encounter was found varied among the respondents. Nearly equal proportion of the students mentioned curiosity and pleasure seeking (31.9 and $34 \%$ ) as their objective behind first sexual intercourse. It is necessary that young people should be made responsible about their sexual behaviour.Slightly over a half $(51.1 \%)$ of the sexually experienced students had single sex partner while nearly a third (31.9\%) of the respondents had two sex partners and $17 \%$ of the sexually experienced respondents had more than two sex partners. Respondents having single sex partner were found to be at less risk ( $41.7 \%$ ) of unsafe sexual behaviour as compared to those having multiple sex partners (52.2\%). Study showed that nearly half of the sexually experienced students $(46.8 \%)$ were involved in unsafe sexual behaviour.

Similar study in Baglung district of Nepal revealed that 79.3 $\%$ of the sexually active students had single partner, $16.5 \%$ had two sex partners while $4.1 \%$ had more than two partners. $44.4 \%$ of the sexually active respondents were involved in unsafe sexual behaviour. Unsafe sexual practice was found $44.8 \%$ and $36.2 \%$ among unmarried boys and girls respectively. (3)

These findings suggest that students should be made aware of the risks associated with multi-partner sex and inconsistent and no condom use.

\section{Conclusion}

Nearly one-fifth students had premarital sex and nearly half of the students had been involved in unsafe sexual behavior. Based on the findings, the study recommends that the major concern should be on making the sexual relations safe and it is therefore necessary to encourage young people to be consistent condom users. Young people should be made responsible about their sexual behaviour for which parents, teachers and media can play an important role.

\section{References:}

$1 \mathrm{MoHP} / \mathrm{DoHS}$. Annual Report Kathmandu Department of Health Services 2010

2 Shrestha RB, Sexual risk behaviour and perception among secondary school students in Panauti Municipality of Kavre District, TU, IOM, Maharajgunj Campus, Maharajgunj, Kathmandu, April 2004

3 Sapkota N, Sexual behaviour and associated factors among Higher Secondary School Students, TU, Institute of Medicine, November, 2008

4 Neupane S, Nichols D, Thapa S, Knowledge and beliefs about HIV/ AIDS among Young People in Urban Nepal, Asia- pacific Journal, December 2003. 